\title{
Indium-Mediated Allylation of Hydroxyphthalides with Acetic Acid as an Additive
}

\author{
Ji Hee Lee, Young Sang Park, Mi Hye Nam, ${ }^{\dagger}$ Seung Hwan Lee, Min Young Cho, ${ }^{\dagger}$ and Cheol Min Yoon ${ }^{\dagger, "}$ \\ Graduate School of Biotechnology, Korea University, Sungbuk-gu, Anamdong 1, 5 ga, Seoul 136-701, Korea \\ ${ }^{\dagger}$ Department of New Material Chemistry, Korea University, Jochiwon, Choongnam 339-800, Korea \\ *E-mail: cmyoon@korea.ac.kr \\ Received November 16, 2004
}

Key Words : Indium, Acetic acid, Allylation, Hydroxyphthalides

Phthalide derivatives represent an important class of naturally occurring lactone. ${ }^{1}$ Some of these compounds showed a biological activity ${ }^{2}$ and also have been used in the treatment of diseases. ${ }^{3}$ A lot of synthetic methods were developed and reported for preparation of phthalide derivatives as target molecules ${ }^{4}$ and starting materials for preparation of other natural products. ${ }^{5}$ Among metalmediated allylation reactions, ${ }^{6}$ indium-mediated allylation ${ }^{7,9}$ has gained popularity in view of the possibility of carrying out the reaction in water and showing different pattern of diastereoselectivity. The organic reaction in aqueous solution can save time and cost by evading a consuming protection and deprotection sequence for certain functional groups containing acidic moiety such as carboxylic acid and alcohol.

Here we report an efficient allylation of hydroxyphthalides 1a and 1b using various allyl bromides and indium in THF in the presence of 1 equiv. of acetic acid (Scheme 1). The allylations in aqueous THF were attempted as well for comparison. For the optimization of allylation, the ratio of indium and cinnamyl bromide in the reactions was fixed in $1: 1.5$ on the assumption of reactive species of allyl indium as a sesquidimeric species. ${ }^{8}$ The allylation reaction of hydroxyphthalide 1a in THF (entry 1, Table 1) was slow and gave a cinnamylated phthalide in low yield even after $24 \mathrm{~h}$ due to incomplete reaction. By the addition of water (entry 2), 1 equiv. of $1 \mathrm{~N} \mathrm{HCl}$ (entry 3 ) or 0.5 equiv. of acetic acid (entry 4) to THF reaction solution as a cosolvent or additives, the allylation gave a cinnamylated phthalide in quantitative yield with increased diastereoselectivity and reduced reaction time as shown in Table 1 . The reaction in the presence of acetic acid is turned out to be faster than that in aqueous solution. Acetic acid rather than $1 \mathrm{~N} \mathrm{HCl}$ solution was a choice of acid additive because of fast reaction rate, easy handling and better diastereoselectivity. 1 equiv. of

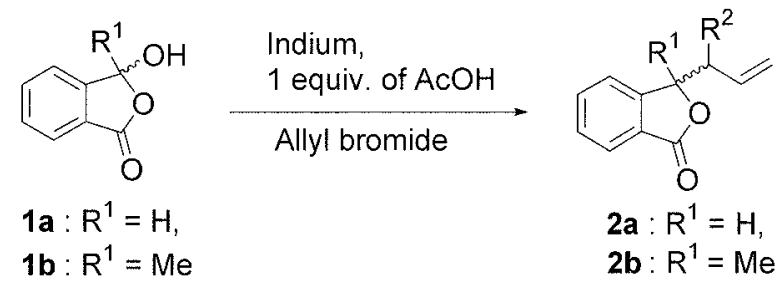

Scheme 1
Table 1. Allylation of hydroxyphthalide 1a with cinnamyl bromide

\begin{tabular}{cccccc}
\hline Entry & Additive & Solvent & $\begin{array}{c}\text { Time } \\
\text { (h) }\end{array}$ & $\begin{array}{c}\text { Ratio of } \\
\text { isomers }^{a}\end{array}$ & $\begin{array}{c}\text { Yield } \\
(\%)^{b}\end{array}$ \\
\hline 1 & & THF & 24 & $1: 1.1$ & 47 \\
2 & & THF/H $\mathrm{H}_{2} \mathrm{O}(4: 1)$ & 24 & $1: 3.4$ & 98 \\
3 & $1 \mathrm{~N} \mathrm{HCl}(1$ equiv. $)$ & $\mathrm{THF}$ & 6 & $1: 2.8$ & 99 \\
4 & $\mathrm{AcOH}(0.5$ equiv. $)$ & $\mathrm{THF}$ & 8 & $1: 3.1$ & 99 \\
5 & $\mathrm{AcOH}(1$ equiv. $)$ & $\mathrm{THF}$ & 5 & $1: 3.7$ & 99 \\
6 & $\mathrm{AcOH}(2$ equiv. $)$ & $\mathrm{THF}$ & 5 & $1: 2.5$ & 99 \\
\hline
\end{tabular}

${ }^{a}$ The ratio of diastereoisomers was determined on the basis of ${ }^{1} \mathrm{H}$ NMR spectrum: The stereochemistry of syn and anti diastereoisomers was not determined. ${ }^{b}$ Isolated yields.

Acetic acid was found to be optimum amount in both reaction rate and diastereoselectivity (entry 5).

The reactions of 3-hydroxyphthalide 1a with various allyl bromides in THF in the presence of 1 equiv. of acetic acid were examined (Method B) and the results are shown in Table 2. The reactions also were tried in aqueous THF (THF : $\mathrm{H}_{2} \mathrm{O}=4: 1$ ) for a comparison (Method A). Generally, the reaction under Method B is faster than that under Method A. The allylations of hydroxyphthalide 1a with various allyl bromides under two conditions gave the corresponding products in high yields in the most cases (entries 1, 2 and 46 , Table 2), whereas the propargylation of hydroxyphthalide 1a with propargyl bromide in aqueous THF did not gave any product. The reaction with propargyl bromide in THF in the presence of acetic acid gave the two products, propargyl and allenyl phthalide in $46 \%$ and $27 \%$ yields, respectively (entry 3 ). The allylation of phthalide 1a with crotyl bromide under the reaction conditions almost did not show any diastereoselectivity (entry 5). In the reaction of allyl bromides with substituents at $\gamma$-position, only the product resulting from $\gamma$ attack was produced (entries 2, 5 and 6).

The reaction did not seem to proceed through the oxocarbenium ion $\mathbf{C}$ generated from a phthalide $\mathbf{1 a}$ under the our present conditions but through allylation of carboxybenzaldehyde $\mathbf{A}$ in the equilibrium with 3-hydroxyphthalide 1a followed by lactonization. ${ }^{9}$ Even if internal chelation effect of indium reagent by carboxylate has been known, ${ }^{10}$ it is not clear that it is operative in our phthalide system under our reaction condition.

We next examined allylation of 3-hydroxy-3-methylph- 
Table 2. Allylation of 3-hydroxyphthalide with various allyl bromides

\begin{tabular}{|c|c|c|c|c|c|}
\hline Entry & $\begin{array}{c}\text { Allyl } \\
\text { bromide }\end{array}$ & $\begin{array}{c}\text { Time } \\
\text { (h) }\end{array}$ & Product & $\begin{array}{l}\text { Method A }{ }^{a} \\
\text { Yield }(\%)^{c}\end{array}$ & $\begin{array}{l}\text { Method B } \\
\text { Yield }(\%)^{c}\end{array}$ \\
\hline & & 24 & & 98 & \\
\hline
\end{tabular}

2<smiles>BrCC=Cc1ccccc1</smiles><smiles>[14CH3]</smiles><smiles>C=CC(c1ccccc1)C1OC(=O)c2ccccc21</smiles>

24<smiles>C#CCC1C=CC=C1C(=O)O</smiles>

3<smiles>C#CCBr</smiles><smiles>[Mg]</smiles><smiles>C=CC1OC(=O)c2ccccc21</smiles>

4<smiles>[B]CC(=C)C</smiles><smiles>[14CH3]</smiles><smiles>C=C(C)CC1=C2C=CC=C2C(=O)O1</smiles>

94

98

99

0

24

5<smiles>CC=CC[B]Br</smiles>

7

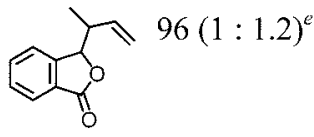

$95(1: 1)^{e}$

6

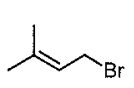

$$
46(27)^{d}
$$

24

7

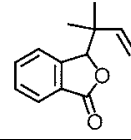

95
Table 3. Allylation of 3-hydroxy-3-methylphthalide with various allyl bromides

Entry $\begin{gathered}\text { Allyl } \\ \text { bromide }\end{gathered}$

${ }^{a}$ Method A: The reactions were conducted with substrate $(0.3 \mathrm{mmol})$ and indium (1.1 equiv.) in THF $(2.4 \mathrm{~mL})$ and water $(0.6 \mathrm{~mL})$ at room temperature for $24 \mathrm{~h}$. ${ }^{b}$ Method B: The reactions were conducted with substrate $(0.3 \mathrm{mmol})$ and indium (1.1 equiv.) in the presence of acetic acid (1 equiv.) in THF (3 mL) at room temperature for $24 \mathrm{~h}$. ${ }^{c}$ Isolated yields. ${ }^{d}$ Only one diastereoisomer formation under two conditions. ${ }^{e}$ Diastereoisomer is ratio (syn and anti): The stereochemistry of two diastereoisomers was not determined yet.

\section{Experimental Section}

thalide $\mathbf{1 b}$ with various allyl bromides under two conditions (method A and B) and the results are shown in Table 3. The allylations of 3-hydroxy-3-methylphthalide are turned out to be less reactive and efficient than that of 3-hydroxyphthalide 1a. Yields of the reactions in THF in the presence of acetic acid are generally better than that obtained from the reaction in aqueous THF solution in all cases. In addition, the diastereoselectivity of the reaction is better in THF in the presence of acetic acid than that of the reaction in aqueous THF (entry 4). The allylation with cinnamyl bromide gave only one diastereoisomer under two reaction conditions (entry 2). The reactions with propargyl bromide (entry 5) and prenyl bromide (entry 6) did not give any identifiable product and the starting material was recovered.

In conclusion, 3-hydroxylphthalide 1a was allylated using indium and various allyl bromides in THF in the presence of 1 equiv. of acetic acid to give the corresponding allylphthalides. However, allylations of 3-hydroxy-3-methylphthalide gave the corresponding allylated phthalides in relatively low yields. Addition of acetic acid as an additive increased yield and diastereoselectivity and accelerated reaction rate.
A typical procedure: Allylation of 3-hydroxyphthalide with cinnamyl bromide. Method A: The reaction in solution of THF $(2.4 \mathrm{~mL})$ and water $(0.6 \mathrm{~mL})$ for $24 \mathrm{~h}$ at room temperature followed by the same work-up as Method B gave a cinnamyl phthalide in $98 \%$ yield. Method B: To a solution of 3-hydroxyphthalide in THF (3 mL) was added cinnamyl bromide (76 $\mu \mathrm{L}, 0.50 \mathrm{mmol}$ ), indium (42.1 mg, $0.37 \mathrm{mmol}$ ) and acetic acid $(19 \mu \mathrm{L}, 0.33 \mathrm{mmol})$ at room temperature under argon. The resulting solution was stirred for $5 \mathrm{~h}$, concentrated under reduced pressure and chromatographed on silica gel (ethyl acetate : hexane $=1: 10$ ). The concentration gave a cinnamyl phthalide in $99 \%$ yield $(82.7 \mathrm{mg})$.

Acknowledgement. The authors wish to acknowledge the financial support of the Korea Science and Engineering Foundation (KOSEF-R05-2003-000-11361-0) made in the program year of 2004 .

\section{References and Notes}

1. Shan, R.; Stadler, M.; Anke, H.; Sterner, O. J. Nat. Prod. 1997, 60, 
804, and references cited therein.

2. Matsuda, H.; Shimoda, H.; Yoshikawa, M. Bioorganic \& Medicinal Chem. 1999, 7, 1445, and reference cited therein.

3. Ogawa, Y.; Wakamatsu, T.; Maruno, M.; Isono, M. Jpn. Kokai Tokkyo Koho JP 07206,844, 1995; Chem. Abstr. 1995, 123, 256503 d.

4. (a) Garibay, P.; Vedso, P.; Begtrup, M.; Hoeg-Jensen, T. J. Comb. Chem. 2001, 3, 332. (b) Mukhopadhyay, R.; Kundu, N. G. Tetrahedron 2001, 57, 9475. (c) Hayat, S.; Rahman, A.-U.; Choudhary, M. I.; Khan, K. M.; Bayer, E. Tetrahedron Lett. 2001, 42, 1647. (d) Sakamoto, M.; Sekine, N.; Miyoshi, H.; Mino, T.; Fujita, T. J. Am. Chem. Soc. 2000, 122, 10210. (e) Jayaraman, M.; Fanwick, P. E.; Cushman, M. J. Org. Chem. 1998, 63, 5736.

5. (a) Ciattini, P. G.; Mastropietro, G.; Morera, E.; Ortar, G. Tetrahedron Lett. 1993, 34, 3763. (b) Mori, S.; Takechi, S.; Shimizu, S.; Kida, S.; Iwakura, H.; Hajima, M. Tetrahedron Lett. 1999, 40, 1165. (c) Mali, R. S.; Babu, K. N. J. Org. Chem. 1998, 63,2488
6. For a recent review, see Yamamoto, Y.; Asao, N. Chem. Rev. 1993, 93, 2207; See also Hosomi, A. Acc. Chem. Res. 1988, 21, 200.

7. (a) Nair, V.; Jayan, C. N. Tetrahedron Lett. 2000, 1091 and reference cited therein. (b) Paquette, L. A.; Rothhaar, R. R.; Isaac, M.; Rogers, L. M.; Roger, R. D. J. Org. Chem. 1998, 63, 5463. (c) $\mathrm{Li}$, C. J. Tetrahedron 1996, 52, 5643. (d) Chan, T. H.; Yang, Y. J. Am. Chem. Soc. 1999, 121, 3228. (e) Araki, S.; Katsumura, N.; Ito, H.; Butsugan, Y. Tetrahedron Lett. 1989, 30, 1581.

8. (a) Marshall, J. A.; Hinkle, K. W. J. Org. Chem. 1995, 60, 1920. (b) Araki, S.; Ito, H.; Butsugan, Y. Synth. Commun. 1988, 18, 453

9. (a) Paquette, L. A.; Mitzel, T. M. J. Am. Chem. Soc. 1996, 118, 1931. (b) Kim, E.; Gordon, D. M.; Schmid, W.; Whitesides, G. M. J. Org. Chem. 1993, 58, 5500. (c) Canonne, P.; Plamondon, J.; Akssira, M. Tetrahedron 1988, 44, 2903.

10. (a) Chen, X.; Hortelano, E. R.; Eliel, E. L.; Frye, S. V. J. Am. Chem. Soc. 1990, 112, 6130. (b) Frye, S. V.; Eliel, E. L.; Cloux, R. J. Am. Chem. Soc. 1987, 109, 1862. 